\title{
The cultural significance of physics and evolution in Francoist Spain: continuity and development in the autarchic period
}

\author{
Clara Florensa ${ }^{1}$ and Xavier Roqué ${ }^{2}$ \\ ${ }^{1}$ Centro Interuniversitário de História das Ciências e da Tecnologia, Faculdade de Ciências, Universidade de Lisboa \\ e-mail: clflorensa@fc.ul.pt \\ ORCID iD: https://orcid.org/0000-0002-2153-2861 \\ ${ }^{2}$ Institut d'Història de la Ciència i Departament de Filosofia, Universitat Autònoma de Barcelona \\ e-mail: xavier.roque@uab.cat \\ ORCID iD: https://orcid.org/0000-0003-3475-2051
}

Submitted: 1 April 2020. Accepted: 9 July 2020.

\begin{abstract}
Science took on several distinct uses and meanings under Francoism. It was exhibited as a token of intellectual prowess, deployed as a mighty diplomatic tool, applied as a resource for industry, and invoked in support of National Catholicism. However, in order to successfully fulfill all these roles, science had first to be cleansed and purified, for it was historically bound to materialism, atheism, and positivism. Physics had developed a mechanical worldview that precluded spiritual agency, and the theory of evolution had deprived man of his privileged place in nature. Could these developments be reversed? Classical physics would not easily serve the needs of the new National Catholic state, but modern physics might do, acting as a model and a tool for biological reasoning. In this paper we describe the various attempts by Spanish scientists, philosophers, and intellectuals to enlist modern physics and a revised version of evolution in the construction of the new regime. They strove to show their spiritual value, to sever them from a soul-less modernity, and to reinstate them within a grand universal Catholic tradition. We discuss the import of their arguments for the simultaneous debates about time, space, matter, life, and evolution, exploring the affinities and tensions between the inert and the living world.
\end{abstract}

KEYWORDS: History of Physics; History of Biology; Physics and Philosophy; Science and Religion; Science and Ideology; Science and Francoism; Evolutionism; Darwinism.

Citation / Cómo citar este artículo: Florensa, Clara and Roqué, Xavier (2021) "The cultural significance of physics and evolution in Francoist Spain: continuity and development in the autarchic period". Culture \& History Digital Journal, 10 (1): e003. https://doi.org/10.3989/chdj.2021.003

RESUMEN: El significado cultural de la física y la evolución en la España franquista: continuidad y desarrollo en el periodo autárquico.- La ciencia tuvo distintos usos y significados en el franquismo. Fue exhibida como logro intelectual, desplegada como herramienta diplomática, aplicada como recurso industrial, e invocada en apoyo al nacionalcatolicismo. Sin embargo, para poder ejercer todos estos papeles, antes tuvo que ser purificada, disociándola del materialismo, el ateísmo y el positivismo. La Física había desarrollado una visión mecánica del mundo que excluía la agencia espiritual, y la evolución había privado al hombre de su lugar privilegiado en la naturaleza. Si la Física determinista clásica no era útil a los fines del nuevo Estado nacionalcatólico, la Física moderna sí podía serlo, y servir como modelo y herramienta para la Biología. En este artículo describimos los intentos de científicos, filósofos e intelectuales españoles por alistar la Física moderna y una versión revisada de la evolución en la construcción del nuevo régimen y mostrar su dimensión espiritual, desgajándolas de una modernidad sin alma y reinstaurándolas en la tradición católica universal. Discutimos la relevancia de estos argumentos para los debates simultáneos sobre el espacio, el tiempo, la materia, la vida y la evolución, explorando las afinidades y las tensiones entre el mundo vivo y el mundo inerte. 
PALABRAS CLAVE: Historia de la Física; Ciencia y Franquismo; Darwinismo; Evolucionismo; Historia de la Biología; Física y Filosofía; Ciencia y religión; Ciencia e ideología.

Copyright: (c) 2021 CSIC. This is an open-access article distributed under the terms of the Creative Commons Attribution 4.0 International (CC BY 4.0) License.

\section{INTRODUCTION}

The mentality of the sage is formed within an environment and within a culture. And in this sense, both in the preparatory process when selecting the facts to be investigated, and in the subsequent formulation of the hypotheses, which crystallize into physical laws, the characteristic fates of that Culture [sic] will be revealed (Pemartín, 1953, p. 150, quoted in Castro-Sánchez, 2018, p. 159).

The cultural history of Francoism has not given as much attention to science as it was given by those in charge of developing the cultural policies of the regime. However, the exploitation of science and technology posed great material, political and cultural challenges. Historians have recently begun to examine the ways in which these challenges were addressed, and this special issue is a clear indication of this historiographic renewal. Those scientists who were not in exile or subject to reprisals not only made themselves useful to the regime, but also collaborated in its construction (Camprubí, 2014; Florensa, 2017a; Herran and Roqué, 2012; Nieto-Galan, 2019). This was much more than an act of self-preservation or rhetoric: it had consequences and it makes sense to analyse it as an attempt to argue for the value of science and to legitimise its use in the dictatorship.

In this article we analyse the construction and dissemination by prominent Spanish establishment intellectuals, scientists and politicians, during the Second Republic and the early years of the Franco regime, of a cultural discourse that integrated physics (relativity, cosmology and quantum mechanics) and biology (evolution) into a worldview that was subject to the rules of metaphysics and religion. Three important characteristics of this construct were its political verticality-the discourse emanated from and was modelled by the ruling elite-, its cross-disciplinary approach-it took the unity of science for granted-, and its international dimension-these efforts were not isolated instances, nor were they restricted to the Franco regime, but rather were based on and echoed those of intellectuals and scientists in other countries.

We will examine the way in which conceptions of matter and life were reinterpreted with the aim of arguing their support of a reactionary Catholic worldview. These ideas, and the implications thereof, did not concern only Spanish intellectuals and scientists. The theory of relativity was as much related to the physics of light and gravity as it was to philosophy, and its implications for the understanding of space, time, and the universe were felt in various cultural and political environments (Galison, Holton and Schweber, 2016; Canales, 2015). Quantum mechanics not only transcended the mechanical understanding of nature at the atomic level, but in doing so it also subverted long-established notions of determinism, matter, causality, and even free will: "Quantum physics is an absolutely central part of modern science, and the fact that the picture of physical reality that it offers is so strange and indeterministic has unsurprisingly proved of great interest to philosophical and religious thinkers" (Dixon, 2008, p. 50; Beller, 1999; Bohr, 1958; Heisenberg, 1955). The cultural and political dimensions of modern conceptions of life and evolution, in addition, are obvious. International debates on these issues reached Franco's Spain where they interacted with the ideas of the new totalitarian state. However, the immediate origins of the Francoist discourse on the natural sciences need to be sought in the Republican period. Certain of its intellectuals and politicians had conspired against the Republic and supported Franco's coup. Those who survived the civil war played an important role in the construction of the cultural significance of physics and biology during the dictatorship.

In the discourse on science and religion, notions about matter and life were frequently linked to positivism, materialism, and atheism. Physics and biology had presented serious problems of interpretation from which, however, physics was considered to have freed itself. Quantum mechanics and relativity were formulated in the interwar years and from World War II onwards physics became a rapidly expanding discipline whose philosophical implications were momentarily ignored, as they added little to the calculations. The intellectual unease that had accompanied the genesis of both theories did not seem that important during the Cold War (Forman, 1987; Kaiser, 2005). As far as biology was concerned, it proved to be a discipline full of promise and attractive possibilities for physicists. The implications of genetics in understanding evolution and life on Earth, as well as the new foundations that physics seemed to provide, were the subject of debate. Among the creators of quantum mechanics, Niels Bohr (1933), Pascual Jordan (1941) and Edwin Schrödinger (1944) all wrote influential essays on the relationship between physics and biology that had a bearing on physics research and moulded the careers of physicists such as Max Delbrück (Aaserud, 1990, ch. 2 and 4). Given this symbiotic relationship between the two disciplines, there is much to be gained from considering biology and physics together and comparing their treatment in public discourses about science.

The Catholic intellectuals of the regime were drawn to certain scientific concepts, such as the uncertainty principle, the expansion of the Universe, and evolutionary 
finalism. How could these concepts support a specific relationship between science and the Catholic doctrine? To the extent that Catholicism was the official religion of the state, this alliance had a political function.

\section{REACTIONARY INDETERMINISM AND VITAL- IST EVOLUTION IN ACCIÓN ESPAÑOLA}

Francoist national-Catholic efforts to link science and religion had their roots in the work of thinkers and scientists who, from the end of the $19^{\text {th }}$ century, argued against the idea of an inevitable conflict. They focused attention on the inherent limitations of science, in order to open it up to metaphysics and religion: it was all about combating materialist atheism with science itself (Brooke, 2014; Nye, 1976; for the Spanish case, cf. Herran, 2012). However, the immediate antecedents of these efforts are in fact to be found in the Republican period and can be traced back to the magazine Acción Española, published by the association of the same name (Badía 1992; González Cuevas 1998; Morodo, 1978, 1980). This anti-Republican publication, active from 1931 until 1937, was created as a doctrinal magazine to defend and disseminate Catholic and pro-monarchy principles. A look at the list of the constituent members of Acción Española helps to give an idea of the power of the network it created, containing as it does well-known names from the political sphere and the Spanish intelligentsia of the Franco regime, along with important names from the aristocracy, industry and the media. José Ibáñez Martín, president of CSIC (Consejo Superior de Investigaciones Científicas, the Spanish National Research Council) for 28 years (1939-1967) and Franco's Education minister for 12 years (1939-1951), was a member of the magazine's board (Camprubí, 2014, p. 57). Around him was a group of prominent intellectuals, mostly supporters of the monarchy but also traditionalists and members of the recently formed Falange party who worked to make Acción Española the mouthpiece of the varied forces supporting the uprising against the Republic. While some historians consider that science was largely irrelevant to this sector of Franco's supporters (Malet, 2020), we argue that Acción Española sought to found a counterrevolutionary school of thought that aimed to be as scientific as possible. Science was an essential element of the work of the counterrevolution (Vegas Latapié, 1987; Florensa 2017a).

The magazine strove to connect modern scientific and technological advances with traditional Spanish values. Indeed, its contributers and board were seeking to achieve hegemony in a Gramscian sense (Nieto-Galan, 2011). They reasoned that "as the social ruling classes we have the responsibility to address the masses and win them over so that they serve the national interest" (Sáinz Rodríguez, 1934, p. 1009). The role of science and technology in the construction of this traditionalist Catholic faction, which would have so much weight in the Franco regime, has tended to be scorned or simply not acknowledged by previous studies. While numerous works address this group of intellectuals and their struggles for power, none stop to analyse the role science played (Alonso Plaza, 1985; Díaz Hernández, 2007; González Cuevas, 2012; Juliá, 2000; Pasamar Alzuria, 1985, 1991a, 1991b; Prades Plaza, 2012; Raja Vich, 2010).

Strong threads link the discourse of the intellectuals of Acción Española with the public discourse about science in post-Civil War Spain. The ideal of the unity of culture and knowledge, including science and the return to tradition and Christian values, would reverberate in the creation of CSIC, in the pages of its journal, Arbor, and in several cultural projects of the so-called Generación del 48 , dedicated to the creation of a Catholic science and involving renowned scientists from across the country (Florensa, 2017a).

According to Acción Española, modern science had ceased to support materialism and positivism and was again supporting faith. Indeed, in the first issue of the magazine Ramiro de Maeztu stated that "physics and metaphysics, the moral and natural sciences, once again lead us to listen to the word of the Holy Spirit" (Maeztu, 1931 , p. 6). Maeztu was here making a reference to the cultural pessimism of authors such as Ostwald Spengler, whose principal works had been available in Spain since the 1920s (Herran and Roqué, 2013). In his classic study of quantum theory in Weimar Germany, Forman (1971) relates the willingness of German physicists to accept acausal explanations with the pressure exerted on them by a hostile intellectual environment (Carson, Kojevnikov and Trischler, 2010). In the Spain of the Second Republic, similarly acausal and indeterminist physical laws found a welcome home in intellectual milieux opposed to Republican values.

In the field of physics, the writer most responsible for disseminating these ideas from the pages of Acción Española was José Pemartín (1888-1954), an engineer and influential political writer (Castro Sánchez, 2018). Worthy of note due to their content and length is the series of articles he wrote on "Physics and the spirit", not because of his fierce critique of the mechanistic and utilitarian view of nature, but rather because he sought in physics the remedy for all the ills of natural science (Pemartín, 1932a, 1932b, 1933a, 1933b, 1933c, 1933d). After their realisation that Newtonian mechanics could not describe the structure of the atom or the behaviour of light, modern physicists had reached the limits of their knowledge of matter. At the same time, reactionary intellectuals were to enthusiastically embrace Heisenberg's uncertainty principle, which limits the accuracy with which the position and speed of an elementary particle can be simultaneously determined: "In the infinitely small, Science, then, scientifically, and of itself, sets an unsurmountable cognitive limit" (Pemartín, 1933a, p. 140, emphasis in the original). This, then, was the proof that science would never achieve "the absolute degree of certainty of a moral value or a logical principle" (Pemartín, 1932b, p. 36).

To complete his historic and epistemological argument, Pemartín included a table running to 10 pages that summarised the development of physics from the time of Galileo, organised in three columns: "names and dates", 
"material elements", and "formal elements". Physicists and philosophers, as well as the different material and formal elements, were classified into "periods": classical or astronomical; energy or heat; mechanical or light; critical or review; symbolic or true. The critical period owed its name to the "increasing complexity and difficulty" of physical theory and the appearance of "contradictions" which would have led to the return of "old critical trends" (Pemartín, 1933a, pp. 134-143). In this way Pemartín justified his inclusion in the table of philosophers such as Antoine Augustin Cournot (1801-1877), Jules Tannery (1848-1910), Émile Boutroux (1845-1921) and Édouard Le Roy (1870-1954), who to varying degrees represented epistemologies of nominalism and conventionalism, along with Pierre Duhem (1861-1916), a known Catholic apologist. For Cournot, science did not develop through the progressive elimination of metaphysics, but to the contrary, it proceeded through the subordination of facts to ideas, or to put it in his terms, from the positive element to the philosophical (Cournot, 1872, pp. 225-226). ${ }^{1}$ Boutroux made the anti-positivist argument that natural laws changed over time and were not capable of capturing the essence of the natural world (Boutroux, 1874). Finally, Duhem defended the existence of an uninterrupted tradition of research dating back to Aristotle, according to which matters of fact could not determine scientific theory (Nye, 1979; Paul, 1979).

However, Pemartín's thinking not only drank from the well of criticism of scientific positivism and the cultural pessimism advocated in Germany by Spengler. It also echoed the work of British scientists who underlined the spiritual dimension of science such as Arthur Eddington, astronomer, science populariser, and great defender of relativity: "In comparing the certainty of things spiritual and things temporal, let us not forget this-Mind is the first and most direct thing in our experience; all else is remote inference" (Eddington, 1929; cf. Pemartín, 1932b, p. 37). Pemartín also quoted the physicist James Jeans, author of The Mysterious Universe, who stood up for the non-mechanistic nature of physical reality, the tentative and speculative nature of science, the limits of human understanding, and the necessity of Creation: "Modern scientific theory compels us to think of the creator as working outside time and space, which are part of his creation, just as the artist is outside his canvas. It accords with the conjecture of Augustine: 'Non in tempore, sed cum tempore, finxit Deus mundum'" (Jeans, 1930, pp. 134, 137-138). For Pemartín, Jeans' spirituality was doubly valuable because it came from a physicist from the country of "the classical positivism of Stuart-Mill, Spencer and Darwin". The assertion of the spiritual did not, then, spring from "within the cathedrals of Philosophy", but rather from "inside the astronomic observatories and the most advanced scientific laboratories of the world" (Pemartín, 1931, p. 89).

With regards evolutionism, Acción Española propagated an anti-Darwinist imaginary shared with reactionaries and conservative factions from across Europe. According to this imaginary, Darwinism was inextricably linked with materialism and communism and was among the alleged causes of the ills of society (Blázquez Paniagua, 2007, 2011; Pelayo 1999, 2008). In 1936, for example, the ultraconservative newspaper El Siglo de Oro applied the sobriquet "devils of great style" to a group of thinkers, Darwin among them, who the author considered "evil wits who ruin the world of the souls and the world of culture" (Gomis, 1936, p. 31).

The expression "devils of great style", as well as the diagnosis of the cultural damage done by Darwinism, came from a work by the Austrian philosopher, sociologist and economist Othmar Spann entitled "Philosophy of Society", which had been circulating among the Spanish intellectual elite. It had been translated and published by the journal promoted by the philosopher José Ortega y Gasset, Revista de Occidente (Spann, 1933), and was simultaneously commented on in the pages of Acción Española. Spann's radical anti-liberal and anti-socialist opinions became prominent ideological weapons for the European right (Haag, 1966, p. 1). As a prophet of the counter-revolution (Polanyi, 1935, p. 363), his ideas were also valued by those keen to bring about a similar revolt in Spain. The fact that Spann's book, which spoke in favour of totalitarian politics and the individualistic rhetoric of fascism, had been published in the Revista de Occidente, sympathetic to the Republican and elitist organisation of the state, was viewed by Maeztu as evidence of the failure of the world situation and the solutions proposed by the political sector of Ortega (González Cuevas, 2006, p. 89). Ramiro de Maeztu cited an excerpt from Spann in Acción Española, which contained the expression used to describe Darwin and his like that was mentioned above:

\footnotetext{
Our age is well-supplied by geniuses through the cinema, vaudeville, the operetta, materialism, naturalism [...] These ape-like geniuses form a battle line that is difficult for true geniuses to overrun. Because their ranks are not only made up of pornographers, tricksters [and] cheap demagogues, but also devils of great style, such as Locke, Hume, Voltaire, Rousseau, Marx, Darwin (Spann, 1933, p. 198, quoted in Maeztu, 1935, pp. 525-526).
}

By citing Spann in this way, Maeztu was trying to associate materialism, rationalism, liberalism, vice and chaos with the devil himself. Darwin's theory of evolution found itself on the dark side of the dichotomy in the ideological and political discourses of the time. The adherence or contribution to liberalism, materialism or communism of these thinkers - in conjunction with their great ability to seduce the public at large-is what had earned them the appellation of devils of great style. But it was Darwin who had contributed like no other to the popular imaginary that was the basis for them being called "ape-like". ${ }^{2}$

The association between materialism and Darwinism was constructed as much from the progressive, socialist and communist sectors - who wished to appropriate this link-as from the conservative sectors-who wanted to attack it. It was embedded in the construction of two opposing social organizations and cultures. As a consequence, evolutionary theories featured in discussions 
about science and society, whether in arguments about the dissemination (or silencing) of ideas, about the direction of research, or about the design of teaching curricula. Furthermore, Darwinism had achieved the status of a standard bearer: "transformism" signified "what many take to be a supreme truth and the greatest bastion of liberal progress" (Reina, 1932, p. 460). In this sense, Darwinism - "this wind of change which changed even the essence of things" (Reina, 1932, p. 460)—was seen as especially dangerous for the Acción Española project. It was the scientific weapon that had encouraged people to believe that they could call into question traditional truths. Its scientific credibility had to be dismantled if they wanted their counterrevolution to also be scientifically based.

It was, thus, fundamentally necessary to refute Darwinism on scientific terms. To do so, Acción Española not only identified Darwinism with Marxism, it also presented it as a scientifically flawed theory: "Darwin's conception is similar to that of Karl Marx. Firstly, no-one believes it. It failed in the laboratories, in the scientific tests it was subjected to" (Vázquez Dodero, 1934, p. 549). Coherently and with the aim of constructing a counterrevolutionary scientific thinking, objections to evolutionary theory were sought from the authority of science. Pemartín wrote:

The science of our century, more solid and demanding, has put Darwinism aside in order to accept only partial, zigzag evolution, with the selective crosses of Mendel and the rapid mutations of De Vries; it has left the great exact and geometric machine of evolution distorted and mouldy (Pemartín, 1934, pp. 1151-1152).

In addition to using the authority and arguments of those international scientists who shared their views, the magazine's writers denounced the fraudulent practices of well-known defenders of Darwinism, such as Ernst Haeckel (Hopwood, 2015). This enabled them to construct the idea of a Darwinian fanaticism, capable of breaking the rules of the scientific game and inventing proof. This argument served to counter their opponents' accusations of their religious fanaticism: "The fanaticism, the bloody-mindedness is on the other side, it is us who steadfastly ride upright in the face of the ideas of our enemies, cognisant of their arguments against us and capable of refuting them and making them disappear" (Maeztu, 1934, p. 1023). They adopted the rhetoric of proven facts and experiments to unseat Darwinism: "There is not a single fact on which to found a theory as essentially experimental as evolution" (Reina, 1932, p. 461).

Up until the 1930s, the explanations of how natural selection worked in terms of inheritance and changes within populations had serious lacunas and had not achieved consensus among the scientific community. However, in the years leading up to the Spanish Civil War, mathematical works on population genetics provided models which allowed the mechanisms of natural selection in creating new species to be explained. These works did not, though, immediately convince the scientific community, and there were those who were reticent and opposed to them (Bowl- er, 1992). Much of this reticence came from biologists who understood evolution as a finalistic or teleological process-its direction established by an end goal and/or as a process that needed a driving or "vital force" beyond mechanistic explanations. Two examples were Jakob Johann von Uexküll and Hans Driesch, who were quoted often in Acción Española. In 1913, the former, a German zoologist and philosopher who was very critical of Darwinism, published a work translated in 1922 by Ortega y Gasset with the title Ideas for a Biological Conception of the World which considered that Darwinism had run its course: "We are on the brink of a scientific bankruptcy whose consequences are as yet incalculable. Darwinism must be erased from the list of standard scientific theories" (von Uexküll, 1922, quoted in Blázquez Paniagua 2004, p. 164). Biologists who took a stand against Darwinism and its arguments were studied, commented on and their views disseminated through the pages of Acción Española.

Giving voice and visibility to this section of the scientific community was a strategic goal, aimed at countering the efforts of scientists keen to use the new models to rescue Darwinism. Again, this cannot be understood as a purely scientific battle. Some of the scientists who promoted the resurgence of Darwinism were also advocates of a progressive, socialist, or communist, vision of science. Among them was John B. S. Haldane (1892-1964), Professor of Genetics at University College London, member of the Communist Party of Great Britain and a prolific science populariser who championed a Darwinist worldview that united biology, physics, maths, chemistry and sociology in order to create new myths for the society of the future (Dronamraju, 2017; Esposito, 2011, p. 42).

Haldane visited Spain in 1933 to attend a literary and scientific congress organised by the International Committee on Intellectual Cooperation of the League of Nations, whose headquarters was in Geneva. The meeting, which took the form of "Conversations" presided over by Marie Curie, brought together intellectuals from diverse branches of knowledge in the Auditorium of the Residencia de Estudiantes, in Madrid. The Residencia was the material concretion of the liberal ideology of the Institución Libre de Enseñanza, the source of all ills in the eyes of the men of Acción Española (Sáenz de la Calzada, 2011). In attendance representing the intelligentsia of Spain were renowned academics such as Miquel de Unamuno, Agustín Calvet (Gaziel) and Gregorio Marañón.

Acción Española derided the event as an attempt to guide Spanish culture from abroad: "Here we have various gentlemen, as well as a few ladies who, with a mandate from Geneva, [met] to elucidate what the future of our culture should be" (Fernández Cuenca, 1933, p. 535). According to the columnist who covered the event, the meeting "gave off, and in its clearest expression, the poisonous perfume of the encyclopedism that led to the French Revolution, married to the old winds of the Reformation and father of all the destructive disturbance of modern humanity" (Fernández Cuenca, 1933, p. 536). In the opinion of Acción Española, "the deliberations of Ge- 
neva lack [...] one thing: God" (Fernández Cuenca, 1933, p. 536). During his stay in Spain, Haldane took the opportunity to lend his support to the Socialist and the Communist parties (Dronamraju, 2017, p. 172). Physics and biology could shape, in any number of ways, a culture, a society and, ultimately, a state.

According to the men of Acción Española, Darwinian evolution belonged to the "edifice of heresies and errors, in which the European intelligentsia has imprisoned the souls of the new generations at the beginning of the $20^{\text {th }}$ century". In their account, Darwinism, mechanistic evolution and evolutionism had spread across Europe in the form of "philosophical and scientific waffle" (Reina, 1932, p. 463) through the actions of intellectuals straying from the orthodox path. In arguing about evolutionism, Acción Española was arguing for the creation of a Catholic orthodox intelligentsia capable of taking the helm and countering these trends from Europe that had already germinated in Spain.

\section{THE CONTINUATION OF THE COUNTERREVO- LUTION}

At the end of the 1940s, the heirs of Acción Españo$l a$, idealogues of the most traditional, reactionary Catholic and monarchist faction of the regime, many of them Opus Dei members, gained control of Arbor, the journal of the Spanish National Research Council (Díaz Hernández, 2011; Prades Plaza, 2012). From this platform they attempted to construct and disseminate a unitary, Catholic and hierarchical science and culture project. The "fight for the cultural conquest of Spain" (Raja Vich, 2010, p. 51), in which they set themselves in competition with other factions of the regime, consisted in dominating as many media and positions of management within the sphere of culture as possible in order to take control of the discourse and win over the ruling elite to their hegemonic aspirations of a worldview that included science.

Names as well-known in the historiography of Francoism as Rafael Calvo Serer (1916-1988) and Florentino Pérez Embid (1918-1974) were part of this group, which at the time was known as the Arbor group, or Generación del 48, but, as we shall see, it also included scientists in its ranks. It was the "most militant and politicised stage" of Arbor (Pasamar Alzuria, 1985, p. 20). From the editorial board of the journal, they sought to further their political and cultural agenda, also through science.

Well-known scientists contributed publications and activities to the construction of a Catholic science. They did so through the so-called Menéndez Pelayo Association. Its objective was "to re-Christianise culture, whose secularization or laicization has spread into all areas of science and art" (Regulations of the Menéndez Pelayo Association, quoted in Florensa, 2015, p. 188). Professors and rectors from Spanish universities, and even government ministers, belonged to this association, as well as two Director Generals of Information (Florensa, 2017a, pp. 314-315).

Among the members of the Menéndez Pelayo Association there was a concentration of members and sympa- thisers of the Arbor group, Pérez Embid and Calvo Serer among them (Florensa, 2017a, pp. 292-295). Each faction of the regime tried to convince the elite and society that their project for Spanish culture was the best to carry Spain forward. They deemed the theoretical and practical conjoining of science and the ideals of Francoism as an inescapable step. Through this cultural campaign, the idea of a Catholic and spiritual science efficiently permeated Franco's Spain.

In this context, the counterrevolutionary conception of physics outlined before the war became hegemonic. Physicists and philosophers insisted on the idea that modern physics was intrinsically limited, which gave it a transcendental dimension (Herran and Roqué, 2013, pp. 215222). In an article on quantum indeterminism published in Anales de Física y Química, the journal of the Spanish Society of Physics and Chemistry, Raimundo Pániker, an early supporter of the Arbor group, successively interpreted Heisenberg's uncertainty principle from the perspective of mathematics, physics and metaphysics, "since the particular interest of this principle lies precisely in the fact that it seems to lead us to the deepest aspects of the behaviour of matter, discovering there a sense of liberty". Freed from the burden of materialism, scientists had furthered the "vertiginous development of modern science, with its double prize of quantum and relativist theories" (Pániker, 1945, pp. 573-575). A year earlier, Xavier Zubiri, a philosopher close to the Falangist intellectuals opposing the Arbor group, had expressed similar sentiments in one of the essays included in Nature, History, God (Naturaleza, Historia, Dios):

That this physics is provisional is not a reproach, but rather, a compliment. A science that finds itself in the situation of not being able to advance without having to return to its principles, is a science that lives by them at all times. It is living science, and not simply a profession. That is, it is science with spirit. And when a science lives, that is, when it has spirit, the scientific and the philosophical [...] can both be found there. Philosophy is nothing if not spirit, intellectual life (Zubiri, 1974, p. 303).

This spiritual twist, in the natural as well as the physical sciences, was sufficiently profound to make its way into texts that were as limited in terms of public access as the exam papers and interview questions for state civil service positions. According to Otero Carvajal (2014, pp. 142-144), physicists used to discuss the development of physics in the compulsory section of the exam relating to the concepts, methods and sources of the discipline. In the submission of the physicist Joaquín Catalá in 1944 for the position of Professor of Theoretical and Experimental Physics at the Universities of Valencia, Granada and Oviedo, he described the development of experimental physics from the time of Galileo and Descartes as a "giant experiment" which had resulted in a "new monstrous Tower of Babel": "In the face of the evidence of our ignorance, the mind of the scientist returns to God as the only absolute Truth" (quoted in Otero Carvajal, 2014, p. 142). ${ }^{3}$ 
The physicist José García Santesmases, candidate for the same professorship, maintained in his submission that in the $20^{\text {th }}$ century physics had experienced "a spiritual revolution, but a revolution executed under the flag of tradition, equally distanced from idealism and materialism and which establishes the intimate and mysterious understanding between the material and the spiritual" (cited in Otero Carvajal, 2014, p. 144). Indeed, these ideas were so common that they can also be found in submissions for state medical exams, such as that of José Botella Llusià:

Relativity, quantum mechanics, the new concepts about empty space have all progressively forced physicists to think ever more metaphysically [...] In this way, the most perfect of the positive sciences, the one that one day seemed to be emancipated from Philosophy [...] today once again $[\ldots]$ admits to the superiority of Philosophy $[\ldots]$ And for this reason, today's physicists $[\ldots]$ are the new scholastic philosophers [...] Hence we are travelling in the opposite direction to that taken by Comte, seeing Physics, Metaphysics and Religion as ever higher levels of human knowledge (cited in Otero Carvajal, 2014, p. 419).

In the state exams for the Chair of Animal Organography and Physiology at the University of Barcelona in 1943, the Opus Dei biologist and collaborator with the Arbor group since its inception, Francisco Ponz Piedrafita (b. 1919), stated that "the theory of evolution has been built upon a series of data that do not amount to a logical proof"; so-called "proofs" were "agreed" data. He also stated that "monistic evolution", which took matter as its sole principle, was "scientifically and philosophically unsustainable" (cited in Otero Carvajal, 2014, p. 284). Finally, he argued that " $[\mathrm{t}]$ he scientific world has once again recognised the traditional doctrine of the autonomy of life, of its unity and purpose: the human being, like all vital beings, is a nature that tends towards its purpose. And this nature has its inner reason in its essential form, which here is the soul or vital principle" (cited in Otero Carvajal, 2014 , p. 285). Ponz Piedrafita therefore advocated a finalist, vitalist and theist evolution, which would become the norm in Franco's Spain.

For Otero Cavajal, Piedrafita's "eccentric" and sui generis arguments do not indicate an advanced knowledge of contemporary physics and biology. Rather they are an "unsustainable" conception of science "in complete accordance with the ideological-cultural postulates of National Catholicism". They are attributable to the "principle of caution, with the objective of not putting at risk his opportunities as a candidate" or else to "an enormous conviction defended with passion as well as epistemological inconsistency" (Otero Carvajal, 2014, pp. 157, 285). We see them, in contrast, as part of an effort to align science with the National Catholic plan, as one more brick in the construction of the New State. This act of cultural resignification had tangible consequences: combining the ideology of Francoism with more recent conceptions of matter and life was taken on board (rather than being considered as imposed) by these working scientists. This objective was in accordance with the principles that moulded their lines of research, their approaches to the object of study and their scientific rhetoric.

The relationship between physics and the life sciences grew closer through this period. The biological implications of radioactivity and the nuclear sciences conditioned their development, from the origins of radiotherapy to the mass production of radioisotopes for agricultural, biological and medical research (Campos, 2015; Creager, 2013; Curry, 2016; Herran, 2008; Santesmases and Romero, 2003). In the 1930s the relationship between biology and quantum mechanics and nuclear physics was much debated. Physics provided new tools for biological analysis, and private foundations, notably the Rockefeller Foundation, redirected physics laboratories towards biological research, for example, the Radiation Laboratory of Ernest Lawrence in Berkeley (California), and Niels Bohr's Institute in Copenhagen (Heilbron and Seidel, 1990; Aaserud, 1990). Physicists such as Max Delbrück before World War II and Maurice Wilkins and Francis Crick in the post-war period, steered their careers towards molecular biology. In parallel with these institutional and professional developments, questions were being asked about the relationship between the laws of physics and our knowledge of living things. In the 1930s and 40s, the physicists Niels Bohr and Pascual Jordan dedicated a number of essays to these questions (Bohr, 1933, 1958; Jordan, 1936, 1941, 1947). The book by Erwin Schrödinger, What is Life, is perhaps the most popular of these reflections on the possibility of using physics and chemistry to explain the phenomena inside a living organism. In his search for answers, Schrödinger appealed directly to the debates around the statistical nature of the laws of physics, determinism, the implications of thermodynamics and evolution, free will, nature and God (Schrödinger, 1944; cf. Moore, 1989, pp. 394-404; Teich, 1975, p. 276).

This debate echoed in Spain through the work of Julio Palacios, a physicist who was active during both the Republic and the Franco periods. In 1947 Palacios published From Physics to Biology (De la física a la biología), his response to Schrödinger's book. Palacios praised Schrödinger's prudence, which he contrasted with the reductionism of "the material physicists of the early part of the century". The reason for the difference was to be found in the crisis of physics, which had stopped being a rational discipline "to become a doctrine that we must call mystical, given its foundation on principles unassailable to reason $[. .$.$] Whoever wants to study modern phys-$ ics needs to liberate themselves from rational prejudice and convince themselves that our knowledge of reality must be based on postulates that have more of dogmas than bodies of reason". Mechanical determinism had prematurely excluded the existence "of whatsoever was incomprehensible, that is, mysterious", and physicists were finally realising their error. The situation had profound implications for biology: "If this happens in the inorganic world, we have more than good reason to expect that the study of living things will reveal to us new marvels and, 
for this reason, we physicists need to enter the field of biology disposed to climb through terrain that rises above ours" (Palacios, 1947, pp. 13-15). Palacios quoted Pascual Jordan (1936) and Carl F. von Weizsäcker (1943) as examples of physicists who adhered to the notion of free will. About Schrödinger's book, Palacios criticised his "lamentable pantheist epilogue", but praised his argument of the irreducible difference between a mechanism and an organism, of whose individual parts Schrödinger said: "the single cog is not of coarse human make, but is the finest masterpiece ever achieved along the lines of the Lord's quantum mechanics" (Schrödinger, 1944, p. 85).

This same interest in connecting physics and biology can also be seen in the choice of speakers at the International Philosophy Congress held in Barcelona in October 1948 to commemorate significant anniversaries of both Francisco Suárez (1548-1617) and Jaime Balmes (18101848). The Dominican Dominique Dubarle (1907-1987), in a presentation on "Scientific Knowledge and Cosmology", talked about the need for a new cosmological synthesis of the physical sciences and life: "Modern physics itself is starting to shine an unexpected light on phenomena beyond the command of its own investigations, such as the phenomena of life" (Dubarle, 1949, p. 43). ${ }^{4}$ Historian and philosopher of science R. de Bengy Puyvallée claimed that physics had attained "an 'arrière monde' [a world behind the scenes], mysterious and extraordinary, beyond the reach of human gesture, where physical determinism and human causality play no role". Modern science did not simply aspire to the domination and exploitation of nature, but rather to "pure knowledge, a deeper exploration of the mysteries of nature" (Bengy Puyvallée, 1949, pp. 241-242). ${ }^{5}$ Dubarle would also discuss the "Evolution and Origin of Man" and "Scientific Determinism and the Miracle" at the International Congress of Apologists which was held in Barcelona and Vic, in celebration of the anniversary of Jaime Balmes, alongside intellectuals from the Arbor group such as the philosopher Ángel González Álvarez, and Catholic scientists from abroad such as the Austrian anthropologist Wilhelm Schmidt and the zoologist Josef Kälin, both professors at the University of Fribourg (Florensa, 2017a, pp. 93-94).

At the same time as these developments, the challenge of counteracting materialism in the natural sciences increased in the 1940s. The so-called Neo-Darwinism, or Modern Synthesis of Evolution, explained evolutionary mechanisms through the theories of genetics and mathematics, particularly from the perspective of population genetics, and it aimed to eliminate all finalist, vitalist and transcendent explanations. Powerful British and American scientific institutions backed this new paradigm. With an emphasis on its dissemination across Europe, the Rockefeller Foundation was to organise and finance conferences and meetings in order to debate the place of Neo-Darwinism in the life sciences (Smocovitis, 2014).

Neo-Darwinism was therefore improving its position in the battle for hegemony. As director of the recently formed UNESCO, created for the universal diffusion of science and culture, the fervently Neo-Darwinist biologist
Julian Huxley (1887-1975), one of Haldane's circle, proposed a new culture project based on a biological worldview that attacked the very roots of Arbor's cultural project. For Huxley, as was fearfully commented on from the pages of Arbor, "the choice was being imposed between a 'scientific' vision and one based on Revelation" (Sierra, 1947, p. 268). Those inverted commas around "scientific" were crucial: Huxley's vision was not scientific, but rather politically biased and full of prejudice.

In order to promote an alternative, internationally endorsed discourse to the non-finalist and anti-transcendental one posited by the Neo-Darwinists, Arbor dedicated a special issue to Biological Evolutionism (Arbor, 1951). ${ }^{6}$ Spanish scientists, such as the Professor of Palaeontology from the Central University Bermudo Meléndez Meléndez and the palaeobotanist of the Madrid Museum of Natural Sciences, Josefa Menéndez Amor, along with foreign scientists such as the German palaeontologist Oskar Kuhn, the American geneticist Richard Goldschmidt and the Swiss zoologist Josef Kälin, contributed to this issue, all writing articles critical of Neo-Darwinism. The zoologist Ponz Pierafita and the microbiologist Emilio Palafox, both Opus Dei members, also joined the project from the outset.

The special issue posited the argument against Neo-Darwinism as a fight against materialism, and, ultimately, against communism, in line with the dichotomy of the Eastern and Western blocks during the Cold War. However, the argument was also presented as a struggle between two scientific paradigms, between two schools of thought on evolution: the Anglo-American, anti-finalist and Neo-Darwinist school of evolution in "the north" against the "southern school of evolution", or "continental evolution movement". The latter was international, defended the notions of finalist evolution and could count on an extensive network of scientists able to question the principles of Neo-Darwinism from a scientific perspective. In this sense, the dispute was framed as a fight between liberalism and capitalism, linked with science and positivism; that is to say, a confrontation between the continental world - traditional, conservative and Catholicand the Anglo-American world-capitalist, positivist and protestant-(Florensa, 2017a, pp. 447-448).

\section{INTERNATIONAL RELATIONS WITHIN THE CATHOLIC SCIENCE PROJECT}

The institutionalisation of the discourse of Acción Española in Franco's Spain was not an isolated development, nor simply the product of an autarchic regime. The Catholic science project, which was hierarchical and state sponsored, in fact had considerable international support. These contacts were cultivated and kept active throughout Francoism.

Members of both the Arbor group and the Menéndez Pelayo Association enjoyed the benefit of a wide list of international contacts thanks to funded trips made by their members in the role of "cultural embassadors" on behalf of the Board of Cultural Relations, such as the histori- 
an Calvo Serer and the palaeontologist Miquel Crusafont (1910-1983) (Acosta, 2013, p. 325; Díaz Hernández, 2011, p. 70). Beyond the individual contacts that were established by their members, both the Arbor group and the Association collaborated with international institutions and projects whose agendas also gave importance to physics and evolutionism. These valuable collaborations were of considerable importance in shaping, legitimising and supporting the project of these Francoist groups of cultural action.

In 1950, Calvo Serer, along with Pániker, attended the annual assembly of the Görres-Gesellschaft zur Pflege der Wissenschaft im Katholischen Deutschland (Görres Society for the Support of Science in Catholic Germany), in Mainz (Díaz Hernández, 2011, p. 290). While there, the men from the Arbor group once again met the Swiss zoologist Josef Kälin. In his review of the meeting for the Spanish newspaper $A B C$, Calvo Serer introduced him as a "Catholic naturalist", thus positioning Kälin among the experts who supported his ideas (Calvo Serer, 1950; Faller, 1964; Görres-Gesellschaft, 1951).

The Görres Society functioned as an important hub of internationalisation for the Catholic science project of the Arbor group. Founded in 1876, its aim was to bring together Catholic scientists in order to counter the increasing secularisation of society. With an agenda similar to that of the Arbor group, the Görres Society hoped to promote (because in Germany it could not impose) a Catholic science supported by Christian principles and strictly scientific methods. Like the men of Arbor, its members believed that science could never contradict faith. The Society created institutes in various countries, among them Spain. $^{7}$

The Spanish Görres Institute, which was destroyed during the Civil War, resurfaced in 1951 and initially established itself in a building owned by CSIC under the management of Hans Juretschke (Aldea, 1974), who was one of those at the heart of the Arbor group. Other members of Arbor, such as the Professor of Anthropology at the University of Barcelona, Santiago Alcobé (19031977), were also actively involved in the Görres Society. One of the objectives of the Görres Institute in Spain was the identification of works by Spanish authors on themes of interest to the Society, with the aim of making them accessible to the German academic community. It also sought to propose joint lines of investigation that fitted with the Society's agenda and interests. The results of such works were then disseminated through the Society's publications, such as the "Spanische Forschungen der Görres-Gesellschaft" ("Spanish Research by the Görres Institute") collection, in which various members of the Arbor group and the Mendéndez Pelayo Asociation published articles (Aschendorff, 2004).

The Görres Society had links with the University of Barcelona, with the Balmesiana Foundation, with CSIC and Opus Dei through people as important as Calvo Serer, Pániker and José María Albareda. The chemist Otto Hahn, awarded the Nobel prize for chemistry in 1944, was also a sympathiser (Görres-Gesellschaft, 1951, pp. 12-13, 21), and other members of the Society included the philosopher Dominique Dubarle and the zoologist and palaeontologist Kälin, who both had close links to the Arbor group. As we have seen, Dubarle and Kälin participated, along with several of the men of the Arbor group, in the session on evolutionism and indeterminism at the Congress of Apologists in Barcelona in 1949. Dubarle contributed to Arbor during the period when Serer and Pérez-Embid were in control. Kälin was one of the three foreign authors invited to participate in Arbor's special issue on biological evolution.

Another international project aligned with the idea of science held by Spanish ideologues, and in which the Arbor group was hugely implicated, was the publication of an ambitious history of the world, Historia mundi, which was to collect together articles by international experts in ten volumes. The project was overseen by Fritz Kern, lecturer at the University of Munich, and financially underwritten by an annual grant from a publishing house in Bern. According to an article in the Spanish newspaper La Vanguardia Española, "Fritz Kern wanted his plan to not only provide a compendium of historic knowledge, but rather something qualitatively different $[\ldots]$ from the point of view of human knowledge and the transcendence of nature" (Múñera, 1959). The first volume appeared in 1952. Eighteen specialists from nine countries, principally continental Europe, had contributed to the twenty articles included in the volume, which was divided into three parts: fossil man and current races on Earth; prehistory; and current populations as vestiges of ancient peoples and cultures (Movius Jr., 1953). From Spain, the prehistorian Almagro Basch and the anthropologist Alcobé dealt with Prehistory (Alcobé Noguer, 1952; Almagro Basch, 1953). Pérez-Embid, Rodríguez Casado and Calvo Serer also contributed. Among the foreign contributors was Kälin (1952).

Historia mundi was an important endeavour for the goals of the Arbor group. It constituted a step towards the international acceptance of their version of history and their idea of culture and science. It was an opportunity "to influence the present and contribute to the configuration of the future", Serer said (Ynfante, 1970, p. 72) and to a certain extent, it achieved that: American Anthropologist, the journal of the American Anthropological Association, reviewed the first volume, considering it an up-to-date work that could be of great use on general anthropology courses (Movius Jr., 1953). The volume itself professed a version of evolutionism in line with that promoted by the men of the Arbor group.

Finally, in May 1957 the Görres Society held the inaugural event, in the auditorium of the University of Munich, of the Institut für die Begegnung von Naturwissenschaft und Glauber (Institute for Science and Faith). Kälin was its main promoter and also its first director. The Institute comprised 27 scientists from eight countries, including Germany, Switzerland, France and Spain, and, in the words of Kälin, "evolutionism as a philosophical-ideological system" was its foundational tenet (Arnould, 2009, p. 7). Apart from being a lecturer at the University of Freiburg, Kälin was also the Rector of the same university, 
Director of the Institut für Zoologie und Vergleichende Anatomie (the Institute for Zoology and Comparative Anatomy), and, at various times, President of the Swiss Societies of Zoology, Anthropology and Palaeontology. $\mathrm{He}$ also had a long list of publications to his name on evolution and its relationship with Catholicism and had been President of the Biology Section of the Görres Society since 1956. In 1964 he would be made Commander of the Order of Saint Gregory the Great by the Vatican in recognition of services he had rendered on a personal level to the Holy See and the Roman Catholic Church (Faller, 1964). With his prestigious scientific positions and his devout Catholic faith, he was the perfect contact for the Arbor group.

The first meeting of the Institute for Science and Faith was devoted to the problems, methods and results of biological evolution, interpreted from both the philosophical and theological point of view. It was held in Bad Homburg, Germany, in 1957. At the meeting, on which an article appeared in Arbor, Spain was represented by Alcobé (Arbor 1958, pp. 77-78). Later, in Spain, Alcobé would speak about the work of the Görres Society and the meeting in Bad Homburg at the "Symposium on current problems in Evolution" organised by Meléndez and the Jesuit palaeontologist Emiliano Aguirre, among others, at the University of Madrid (Templado, 1960, pp. 101-102). The lectures at the Bad Homburg meeting were published in a book that would be reviewed by the Jesuit and lecturer from the University of Munich and the Faculty of Theology and Philosophy at Frankfurt, Adolf Haas (Haas, 1960). In 1959, the Spanish journal Orbis Catholicus published an article by Haas on "contemporary Neo-Darwinism" where he argued that it was "necessary to rethink what creation and evolution actually meant in order to incorporate the biological discoveries into the great Western spiritual tradition" (Haas, 1959, p. 384). In 1962, he would also jointly publish a book on evolution and the Bible with his friend the Swiss palaeontologist Johannes Hürzeler, curator of the Vertebrates Section at the Natural History Museum, and a Zoology lecturer at the university, in Basel, who often collaborated with Crusafont. The following year Haas published another book, with Meléndez, in the Spanish edition of which Crusafont and Aguirre also participated (Haas and Hürzeler, 1962; Haas, Lator and Meléndez, 1963; N. G., 1964).

Among those contributing to the book, which collected together the conferences held as part of the second session of the Institute of the Görres Society, were the Jesuit anthropologist from the Pontifical University in Rome and consultor on evolution of the Second Vatican Council, Vittorio Marcozzi (1908-2005), the Professor of Palaeontology from the Sorbonne, Jean Piveteau (1899-1991), Kälin and Dubarle, all of them critics of Neo-Darwinism. Entitled The Evolutionary Interpretation of Human Corporality, the book presented the history of human evolution from a biological, philosophical and theological perspective, seeking to relate scientific knowledge of the natural world to Christian revelation (Marcozzi et al., 1960).

The debate generated by these initiatives was impor- tant for the public construction of Spanish Catholicism. Significantly, of the 250 works published by the Catholic publishing house The Library of Christian Authors (Biblioteca de Autores Cristianos, BAC), which was strictly religious and declared of "national interest" by Franco's government, only two were scientific in content: The Origen of Life and Man (Haas, Lator and Meléndez, 1963) and Evolution (Crusafont, Meléndez and Aguirre, 1966).

The second of these, the collection Evolution, is, in the view of Catalá-Gorgues $(2017$, p. 7$)$ a "turning point in the reclaiming of public space for evolutionist studies in Spain". Indeed, it is the first work of popular science on such a grand scale with such a wide distribution which contained clearly Neo-Darwinist contributions, such as that of the Professor of Population Genetics at the University of Barcelona Antoni Prevosti. This change gradually gained standing from the end of the 1960s on. However, we think that it is also important to highlight the historical continuities of this work, the reason, in fact, that the BAC published it. Its three editors and up to a third of its authors (which accounted for approximately half the contributions) were members of, or collaborated with, the Menéndez Pelayo Association (Florensa, 2017b). Evolution sought to build a genuinely Spanish and interdisciplinary debate on the subject of evolution and, as such, the book perpetuated the desire to create a synthesis between science and revelation.

The application in Spain of this transnational project to further a Catholic science can, in some aspects, be considered unique, for instance in terms of the visibility it acquired and the degree to which it was institutionalised. However, the project cannot be understood as simply the product of an autarchic national Catholicism that was internationally and scientifically isolated. The project of the men of the Arbor group and the Menéndez Pelayo Asociation transcended the borders of Spain. Indeed, these shared concerns generated a transnational network of people as well as cultural and scientific exchanges.

\section{CONCLUSIONS}

We have argued that science, because of its relationship with modernity, despiritualisation and secularisation, was a key element in the theoretical legitimisation of Francoism. Intent on restoring the hegemony of Catholicism, Francoist ideologues sought to construct a Catholic science, thereby establishing a doctrinal body that would legitimate the regime. One of its principal aims was to achieve the synthesis between science and faith, between culture and dogma, with culture being understood according to the Llullian ideal, that is to say, as a tree where all branches of knowledge, including the sciences, were attached to the trunk of theology. In these efforts to conceptualise the sciences, physics and biology both played important, but not always parallel, roles. Just when physics seemed to have at last achieved the desired synthesis, allowing uncertainty to enter the realm of science and thus opening the doors to mystery and to God, evolution resisted it, and with ever more force and therefore creat- 
ing an especially problematic hurdle. The legitimisation of Francoist ideology through science and the reciprocal modelling of science on the basis of Francoism cannot be disentangled from their historic, political, economic and religious foundations. The various factions of the regime had different conceptions of exactly what the culture of the New State should be and how it should be implemented, although a consensus did exist on what it was to be based on: the "new culture" should form a coherent, unitary whole, at the service of God and the State and guided by the search for Truth. In their words, they were seeking a Catholic synthesis of culture advocating against specialisation and for the integration of all the sciences, from palaeontology and biochemistry to history and theology.

Science, however, is virtually absent in the abundant recent literature on culture in Francoism (Florensa, 2017a, p. 22). The Catholic science project of the Arbor group, along with its view of history and its political aims, have been studied in detail. In contrast, the role of science in the cultural projects of these ideologues of the regime has been mostly neglected. The omission is made even more surprising when we take into account that one of the most important platforms of the project was Arbor, the official journal of the Spanish National Research Council (CSIC).

The exhaustive and rigorous study of this faction by the historian Onésimo Díaz Hernández in his book Rafael Calvo Serer and the Arbor group analyses the ideological and political standpoint of the journal under this group's control. Díaz, however, does not consider its scientific content. One example is the special issue on biological evolutionism put together by the Arbor group and published in the journal in 1951. While other special issues are analysed in detail, Díaz only dedicates two sentences to this particular one: "The issue in June was dedicated to the problem of biological evolution. The introduction and one of the works were written by Saumells" (Díaz Hernández 2011, p. 351).

This article brings to the fore the counterrevolutionary political doctrinal discourse prior to the Civil War, not recognised until very recently in the historiography (Florensa, 2017a), which was intent on constructing a Catholic science that was anti-materialist, finalist and theist, grounded in and supported by scientific arguments and authorities. Through our analysis of the treatment of the laws of physics and evolution we have outlined the roots and precedents of the discourse on science that permeated and took hold under Franco's rule and the discourses and their proponents in the pages of Acción Española and its line of reasoning. These discourses played an important role in the way science was dealt with in Franco's Spain and within the project of the construction of the New State. Due to the purge of intellectuals from the universities and the privileged positions that promoters of this project held in terms of the management of culture and information, the impact, diffusion and possibilities of implementation of the Spanish Catholic science project was without parallel in any other European country. For the same reason, their discourse also reached levels of self-indulgence and self-centredness that could lead one to think that it was a unique project, an autarchic cultural product of Franco- ism. But the truth is that this project was supported internationally by various Catholic and conservative factions.

\section{ACKNOWLEDGEMENTS}

The research for this article was conducted under the projects 2017 SGR 01138, PID2019-106743GB-C22 and PID2019-105131GB-I00. Clara Florensa acknowledges the support of the Escoles Universitàries Gimbernat, Spain, through a six-months research fellowship, and of the Fundação para a Ciência e Tecnologia, Portugal, project UIDP/00286/2020.

\section{NOTAS}

1 "Ainsi le progrès de la science ne consiste pas précisément à se dépouiller de plus en plus de métaphysique pour passer à l'état rigoureusement positif, mais au contraire à soumettre de plus en plus le fait à l'idée, l'élément positif à l'élément philosophique qui lui donne l'organisation ou la forme par où elle se distingue de l'agrégat purement empirique" (Cournot, 1872, pp. 225-226).

2 Although the adjective simian might have been, before Darwin, associated with the devil, with a lack of humanity, or with imitation without intellect, the media diffusion of Darwin's theory of evolution created powerful images that, building on previous ones, captured the popular imagination in terms of the man-ape relationship (Corbey and Bert, 1995; Hochadel, 2010).

3 Catala had plagiarised the argument of a text from 1940 by the chemist Octavio Foz Gazulla, Physics today: "After three centuries, the huge experiment destined to replace metaphysical and mystic knowledge by a rationalised experimental science can be considered to be finished: the work of Galileo and Descartes has been revealed as the seed of a new tower of Babel [...] However you want to see it, scientific speculation has abandoned rationalism and returned to God" (Foz, 1940, pp. 27, 40).

4 "La physique moderne commence même de projeter une certaine lumiére inattendue jusque sur des phénomenes extérieurs à l'ordre propre de ses investigations, tels les phénomenes de la vie".

5 "Remarquons enfin que si la notion de physique construite par l'homme pour accroître sa puissance sur le monde, fait de plus en plus place à l'humain, les théories nouvelles étendent leur domaine à un extraordinaire et mystérieux 'arrière monde' qui n'est plus à la portée du geste humain, où determinisme physique et causalité humaine ne jouent plus. Mais d'autre part, ces mêmes théories expliquent dès maintenant une foule de faits à l'échelle humaine dont les positivistes refusaient d'anlyser les causes profondes. On s'aperçoit alors que la science nouvelle ne vise plus seulement à la puissance, mais bien plutôt à une connaissance pure, à une exploration plus poussée des mystères de la nature, à la satisfaction de notre appétit de connaître. Rechercher les raisons dans un monde infinitement riche où la puissance humaine est presque nulle, voilà qui donne une valeur nouvelle et une grande signification à la science qui n'était jusqu'ici que centrée sur la catégorie de l'utile, valeur et signification qui montrent que science et philosophie se trouvent intimement liées pour le progrès du savoir humain".

6 The encyclical Humani Generis, published by Pope Pío XII in 1950 , included evolutionism among the "false opinions against Catholic doctrine" prevalent in contemporary society and linked it to communism. However, the encyclical also encouraged debate about theories of evolution, particularly between cultured Catholic men such as those of the Arbor group and their scientist collaborators. For more on the impact of the encyclical on the debate about evolutionism in Spain, see Blázquez Paniagua (2004: 261-264), Catalá-Gorgues (2014) and Florensa (2017a: 147-149). 
7 According to Sandra Rebok, "the Görres Society understood by 'Catholic science' 'the science of Catholic scholars who in all purely scientific questions do not know any rules other than those of general scientific procedures'. However, it 'wholeheartedly believed in the principle that there is no contradiction between faith and knowledge", (Rebok, 2011: 174-175).

\section{REFERENCES}

Aaserud, F. (1990) Redirecting Science. Niels Bohr, Philanthropy, and the Rise of Nuclear Physics. Cambridge: Cambridge University Press

Acosta, C. (2013) "Un pie en el cielo y otro en la ciencia. Las interacciones productivas de Miquel Crusafont (1910-1983)". Dynamis, 33 (2), pp. 321-342. doi: https://doi.org/10.4321/S021195362013000200003

Alcobé Noguer, S. (1952) "Die Biodynamik des afrikanischen Kontinents". In Historia Mundi. Bern/Munchen: Francke/Lehnen, pp. $175-188$.

Aldea, Q. (1974) "Una Asociación ejemplar de intelectuales: La Sociedad Görres”, Arbor, 87 (338), pp. 97-107.

Almagro Basch, M. (1953) "Das Alte Nordafrika”. In Historia Mundi. Bern: Francke Verlag, pp. 101-127.

Alonso Plaza, J. M. (1985) "Arbor de 1950 a 1956: Las bases ideológicas de un proyecto político tradicional-integrista". Arbor, 122 (479), pp. 39-58

Arbor (1951) "Número extraordinario dedicado al problema de la evolución biológica". Arbor 19 (66), pp. 181-387.

Arbor (1958) "Del mundo intelectual". Arbor, 39 (145), pp. 76-78.

Arnould, J. (2009) "Kosmologie und Schöpfung" In: S. Borrmann and G. Rager, ed., Kosmologie, Evolution und evolutionäre Anthropologie. Freiburg / München: Verlag Karl Alber, pp. 107122

Aschendorff, V. (2004) Spanische Forschungen der Görres-Gesellschaft. Münster: Aschendorff.

Badía, J. (1992) La revista Acción Española, aproximación histórica y sistematización de contenidos. $\mathrm{PhD}$ dissertation, Universidad de Navarra.

Beller, M. (1999) Quantum Dialogue. The Making of a Revolution. Chicago: The University of Chicago Press.

Bengy Puyvallée, R. de (1949) "La notion d'espace et la notion de temps en theorie cosmologique". In Congreso Internacional de Filosofía. Con motivo del Centenario de los Filósofos Francisco Suárez y Jaime Balmes. Barcelona, 4-10 octubre 1948. Vol. 2. Madrid: Instituto Luis Vives de Filosofía, pp. 231-242.

Blázquez Paniagua, F. (2004) El Evolucionismo en España y la Síntesis Neodarwinista (1939-1970). PhD dissertation, Universidad Autónoma de Madrid.

Blázquez Paniagua, F. (2007) "Notas sobre el debate evolucionista en España (1900-1936)”. Revista de Hispanismo Filosófico, 12, pp. 1-19.

Blázquez Paniagua, F. (2011) "Darwin y el darwinismo en España a través de sus centenarios $(1909,1959,1982)$ ). In: E. Ausejo, J. M. Cobos, and A. Pulgarin, eds., Actas del X Congreso de la Sociedad Española de Historia de la Ciencia y de las Técnicas, Badajoz: SEHCYT, pp. 133-140.

Bohr, N. (1933) "Light and Life". Nature, 131, pp. 421-423, $457-$ 459. doi: https://doi.org/10.1038/131421a0

Bohr, N. (1958) Atomic Physics and Human Knowledge. New York: John Wiley \& Sons.

Boutroux, É. (1874) De la contingence des lois de la Nature. París: Germer Baillière.

Bowler, P. J. (1992) The Eclipse of Darwinism: Anti-Darwinian Evolution Theories in the Decades Around 1900. Baltimore: Johns Hopkins University Press.

Brooke, J. H. (2014) Science and Religion. Some Historical Perspectives. Cambridge: Canto Classics ed. Cambridge University Press.

Calvo Serer, R. (1950) “AA dónde nos conduce la ciencia?”. $A B C$, 5 December, p. 9.
Campos, L. A. (2015). Radium and the Secret of Life. Chicago and London: The University of Chicago Press.

Camprubí, L. (2014) Engineers and the Making of the Francoist Regime. Cambridge, MA: MIT Press.

Canales, J. (2015) The Physicist and the Philosopher. Princeton, NJ: Princeton University Press.

Carson, C., Kojevnikov, A. and Trischler, H., eds. (2010) Weimar Culture and Quantum Mechanics. Selected Papers by Paul Forman and Contemporary Perspectives on the Forman Thesis. London: World Scientific Publishing Company, Singapore: Imperial College Press.

Castro Sánchez, Á. (2018) La utopía reaccionaria de José Pemartín (1888-1954). Una historia genética de la derecha española. Cádiz: Servicio de Publicaciones de la Universidad de Cádiz.

Catalá-Gorgues, J. I. (2014) "Spain and Portugal". In: S. Blancke, H. H. Hjermitslev, and P. C. Kjærgaard, eds., Creationism in Europe. Baltimore: Johns Hopkins University Press, pp. 31-49.

Catalá-Gorgues, J. I. (2017). "Introducción. La Evolución desde una perspectiva histórica”. Evolución, 12 (1), pp. 5-10.

Corbey, R and Theunissen, B., eds. (1995) Ape, Man, Apeman: Changing Views since 1600. Leiden: Leiden University.

Cournot, A.-A. (1872) Considérations sur la marche des idées et des événements dans les temps modernes. Vol. II. Paris: Hachette.

Creager, A. N. H. (2013) Life Atomic. A History of Radioisotopes in Science and Medicine. Chicago and London: The University of Chicago Press.

Crusafont, M., Meléndez, B. and Aguirre, E. (1966) La Evolución. Madrid: Editorial Católica (Biblioteca de Autores Cristianos).

Curry, H. A. (2016) Evolution Made to Order. Plant Breeding and Technological Innovation in Twentieth-Century America. Chicago and London: The University of Chicago Press.

Díaz Hernández, O. (2007) "Las revistas culturales en la España de la posguerra (1939-1951): Una aproximación”. Cuadernos del Instituto Antonio de Nebrija, 10, pp. 201-224.

Díaz Hernández, O. (2011) Rafael Calvo Serer y el grupo Arbor. València: Universitat de València.

Dixon, Th. (2008) Science and Religion: A Very Short Introduction. Oxford: Oxford University Press.

Dronamraju, K. R. (2017) Popularizing Science: The Life and Work of JBS Haldane. Oxford/New York: Oxford University Press.

Dubarle, D. (1949) "La connaissance scientifique et la cosmologie". In Congreso Internacional de Filosofía. Con motivo del Centenario de los Filósofos Francisco Suárez y Jaime Balmes. Barcelona, 4-10 octubre 1948. Vol. 2. Madrid: Instituto Luis Vives de Filosofía, pp. 5-44.

Eddington, A. S. (1929) Science and the Unseen World. New York: MacMillan.

Esposito, M. (2011) "Utopianism in the British Evolutionary Synthesis". Studies in History and Philosophy of Biological and Biomedical Sciences, 42, pp. 40-49. doi: https://doi.org/10.1016/j. shpsc.2010.11.007

Faller, A. (1964) "Josef Kälin: 1.8.1903-13.11.1965". Bulletin der Naturforschenden Gesellschaft Freiburg, 55, pp. 198-208.

Fernández Cuenca, C. (1933) "Mundo de la Cultura. I. Nada menos que el porvenir de la cultura". Acción Española, 29, pp. 535-547.

Florensa, C. (2015) "Por una ciencia católica en España: La Asociación Menéndez Pelayo, una red de contactos”. In: V. Bellver, F. D’Amaro, I. Molina, and J. Ramos, eds., Otras voces, otros ámbitos: los sujetos y su entorno. Nuevas perspectivas de la historia sociocultural, València: Universitat de València, pp. 184-190.

Florensa, C. (2017a) Els discursos sobre l'evolució en el franquisme (1939-1967). La Generación del 48 y La evolución sin problema. $\mathrm{PhD}$ dissertation, Universitat Autònoma de Barcelona.

Florensa, C. (2017b) "Contexto histórico, político y cultural de la gestación del libro La Evolución”. Evolución, 12 (2), pp. 5-12.

Forman, P. (1971) "Weimar Culture, Causality, and Quantum Theory, 1918-1927: Adaptation by German Physicists and Mathematicians to a Hostile Intellectual Environment”. Historical Studies in the Physical Sciences, 3, pp. 1-115. doi: https://doi. org/10.2307/27757315 
Forman, P. (1987) "Behind quantum electronics: National security as basis for physical research in the United States, 1940-1960". Historical Studies in the Physical and Biological Sciences 18 (1), pp. 149-229. doi: https://doi.org/10.2307/27757599

Foz Gazulla, O. (1940) La física actual. Madrid: Ediciones Escorial.

Galison, P. L., Holton, G. and Schweber, S. S., eds. (2016) Einstein for the 21st Century. Princeton and London: Princeton University Press.

Gomis, J. B. (1936) "Demonios de gran estilo". El Siglo Futuro, 28, p. 31.

González Cuevas, P. C. (1998) Acción Española: teología política y nacionalismo autoritario en España, 1913-1936. Madrid: Tecnos.

González Cuevas, P. C. (2006). “Ortega y Gasset ante las derechas españolas". Revista de Estudios Políticos, 133, pp. 59-116.

González Cuevas, P. C. (2012) "Punta Europa y Atlántida: Dos respuestas a la crisis de la teología política (1956-1970)". Historia y Política, 28, pp. 109-138.

Görres-Gesellschaft (1951) Jahresbericht der Görres-Gesellschaft 1950. Köln: Kommissions-Verlag.

Haag, J. J. (1966). Othmar Spann and the Ideology of the Austrian Corporate State. Houston: Rice University.

Haas, A. (1959) “Darwin”. Orbis Catholicus, 2, pp. 366-384.

Haas, A. (1960) "Naturwissenschaft und Theologie". Münchener Theologische Zeitschrift, 11 (2), pp. 146-149.

Haas, A. and Hürzeler, J. (1962) Evolution und Bibel. München: Rex-Verlag.

Haas, A., Lator, F. and Meléndez, B. (1963) Origen de la vida y del hombre. Madrid: Editorial Católica (Biblioteca de Autores Cristianos).

Heilbron, J. L. and Seidel, R. W. (1990) Lawrence and His Laboratory. A History of the Lawrence Berkeley Laboratory, Volume I. Berkeley: University of California Press.

Heisenberg, W. (1955) Das Naturbild der modernen Physik. Hamburg: Rowohlt.

Herran, N. (2008) Aguas, semillas y radiaciones. El Laboratorio de Radiactividad de la Universidad de Madrid, 1904-1929. Madrid: CSIC,

Herran, N. (2012) " 'Science to the Glory of God'. The Popular Science Magazine Ibérica and its Coverage of Radioactivity, 19141936". Science \& Education, 21, pp. 335-353. doi: https://doi. org/10.1007/s11191-010-9291-6

Herran, N. and Roqué, X, eds. (2012) La física en la dictadura. Físicos, cultura y poder en España, 1939-1975. Bellaterra: Servei de Publicacions de la Universitat Autònoma de Barcelona.

Herran, N. and Roqué, X. (2013) "An Autarkic Science: Physics, Culture, and Power in Franco's Spain". Historical Studies in the Natural Sciences, 43 (2), pp. 202-235. doi: https://doi. org/10.1525/hsns.2013.43.2.202.

Hochadel, O. (2010). "Darwin in the Monkey Cage: The Zoological Garden as a Medium of Evolutionary Theory". In D. Brantz, ed., Beastly Natures: Animals, Humans, and the Study of History. Charlottesville: University of Virginia Press, pp. 81-107.

Hopwood, N. (2015) Haeckel's Embryos: Images, Evolution, and Fraud. Chicago: University of Chicago Press.

Jeans, J. (1930) The Mysterious Universe. Cambridge: Cambridge University Press.

Jordan, P. (1936) Anschauliche Quantentheorie: eine Einführung in die moderne Auffassung der Quantenerscheinungen. Berlin: Springer.

Jordan, P. (1941) Die Physik und das Geheimnis des organischen Lebens. Braunschweig: Vieweg.

Jordan, P. (1947) Das Bild der Modernen Physik. Hamburg: Stromverlag,

Juliá, S. (2000) "Intelectuales católicos a la reconquista del Estado". Ayer, (40), pp. 79-103.

Kaiser, D. (2005) Drawing Theories Apart. The Dispersion of Feynman Diagrams in Postwar Physics. Chicago and London: The University of Chicago Press.

Kälin, J. (1952) "Die ältesten Menschenreste und ihre stammesgeschichtliche Deutung". In Historia mundi. Bern/München: Francke Verlag/Lehnen Verlag, pp. 33-98.
Maeztu, R. de (1931) “Acción Española”. Acción Española, 1 (1), pp. 1-7.

Maeztu, R. de (1934) "El banquete de Acción Española. Discurso de D. Ramiro de Maeztu”. Acción Española, 46, pp. 1020-1025.

Maeztu, R. de (1935) "El espíritu en la Historia". Acción Española, 15 (72), pp. 524-542.

Malet, A. (2020) "Science and power: Francoist Spain (1939-1975) as a case study". Centaurus, 61 (1-2), pp. 111-132. doi: https:// doi.org/10.1111/1600-0498.12210

Marcozzi, V., Kälin, J., Piveteau, J., Dubarle, D., Volk, H. and Rahner, K. (1960) Die evolutive Deutung der Menschlichen Leiblichkeit. Freiburg: Karl Alber Verlag.

Moore, W. (1989) Schrödinger. Life and Thought. Cambridge: Cambridge University Press.

Morodo Leoncio, R. (1978) "La formalización de Acción Española". Revista de Estudios Políticos, 1, pp. 29-48.

Morodo Leoncio, R. (1980) Acción Española. Orígenes ideológicos del franquismo. Madrid: Tucar.

Movius Jr., H. L. (1953) "Book Reviews: 'Historia Mundi. Ein Handbuch der Weltgeschichte in zehn Bändern",. American Anthropologist (55), pp. 713-714.

Múñera, J. (1959) “"Historia Mundi”,. La Vanguardia Española, 25 November, p. 13.

N. G. (1964) "Origen de la vida y del hombre, por Adolfo Haas," $A B C, 5$ March, p. 51.

Nieto-Galan, A. (2011) "Antonio Gramsci Revisited: Historians of Science, Intellectuals, and the Struggle for Hegemony". History of Science 49, pp. 453-478. doi: https://doi. org/10.1177/007327531104900404

Nieto-Galan, A. (2019) The Politics of Chemistry. Science and Power in Twentieth-Century Spain. Cambridge, Cambridge University Press.

Nye, M. J. (1976) "The Moral Freedom of Man and the Determinism of Nature: The Catholic Synthesis of Science and History in the Revue des Questions Scientifiques". The British Journal for the History of Science, 9, pp. 274-292. doi: https://doi. org/10.1017/S0007087400014862

Nye, M. J. (1979) "The Boutroux circle and Poincaré's conventionalism". Journal of the History of Ideas, 40, pp. 107-120. doi: https://doi.org/10.2307/2709262

Otero Carvajal, L. E. (2014) La universidad nacionalcatólica. La reacción antimoderna. Madrid: Universidad Carlos III de Madrid.

Palacios, J. (1947) De la física a la biología. Madrid: Ínsula.

Pániker, R. (1945) "El indeterminismo científico". Anales de Física y Química, 41, pp. 573-605.

Pasamar Alzuria, G. (1985) "Cultura católica y elitismo social: La función política de Arbor en la posguerra española”. Arbor, 122 (479-480), pp. 17-38.

Pasamar Alzuria, G. (1991a) Historiografía e ideología en la postguerra española: la ruptura de la tradición liberal. Zaragoza: Universidad de Zaragoza

Pasamar Alzuria, G. (1991b) "Política, ciencia y cultura: Una aproximación al análisis de Arbor (1944-1950)". Estudis d'Història Contemporània del País Valencià, 9, pp. 121-138.

Paul, H. W. (1979) The Edge of Contingency: French Catholic Reaction to Scientific Change from Darwin to Duhem. Gainesville: University Press of Florida.

Pelayo, F. (1999). Ciencia y creencia en España durante el siglo XIX: la Paleontología en el debate sobre el darwinismo. Madrid: CSIC.

Pelayo, F. (2008): "Darwinism and Paleontology: Reception and Diffusion of the Theory of Evolution in Spain". In: E.-M. Engels and T. F. Glick, ed., The reception of Charles Darwin in Europe, vol. 2, London: Continuum, pp. 386-399.

Pemartín, J. (1931) "The Mysterious Universe, por Sir James Jeans". Acción Española, 1, pp. 88-91.

Pemartín, J. (1932a) "La física y el espíritu (I)". Acción Española, 3, pp. 595-604.

Pemartín, J. (1932b) "La física y el espíritu (II)”. Acción Española, 4, pp. 27-37. 
Pemartín, J. (1933a) "La física y el espíritu (III)". Acción Española, 4, pp. 131-146.

Pemartín, J. (1933b) "La física y el espíritu (IV)”. Acción Española, 4 , pp. $248-256$

Pemartín, J. (1933c) "La física y el espíritu (V)”. Acción Española, 4 , pp. $347-356$

Pemartín, J. (1933d) “La física y el espíritu (VI)”. Acción Española, 4, pp. $449-458$

Pemartín, J. (1934) "Nuevas orientaciones transformistas". Acción Española, 6 (47), pp. 1151-1155.

Pemartín, J. (1953) "Condicionamientos antropológicos de la ciencia y de la técnica modernas". Revista de Filosofía, núm. 44, pp. 148-155.

Polanyi, K. (1935). "The Essence of Fascism". In: J. Lewis, J., K. Polanyi and D. K. Kitchin, K, eds., Christianity and the Social Revolution, 1933-1934. London: Victor Gollancz, pp. 359-394.

Prades Plaza, S. (2012) Escribir la Historia para definir la nación: la generación de 1948. $\mathrm{PhD}$ dissertation, Universitat de València.

Raja Vich, A. (2010) El 'Problema de España' bajo el primer franquismo, 1936-1956. El debate entre Pedro Laín Entralgo y Rafael Calvo Serer. $\mathrm{PhD}$ dissertation, Universitat Pompeu Fabra.

Rebok, S. (2011) "Las primeras instituciones científicas alemanas en España: los comienzos de la cooperación institucional en los albores del siglo XX”. Arbor, 187 (747), pp. 169-182.

Reina, J. (1932) "El liberalismo y la verdad. IV. Inmutabilidad y mutabilidad. Transformismo". Acción Española, 17, pp. 460-467.

Sáenz de la Calzada, M. (2011) La Residencia de Estudiantes: Los Residentes. Madrid: CSIC

Sáinz Rodríguez, P. (1934) "El banquete de Acción Española. Discurso de D. Pedro Sáinz Rodríguez". Acción Española 46, pp. 1007-1015.
Santesmases, M. J. and A. Romero eds. (2003) La física y las ciencias de la vida en el siglo XX: radiactividad y biología. Madrid: Universidad Autónoma de Madrid.

Schrödinger, E. (1944) What is Life. The Physical Aspect of the Living Cell. Cambridge: Cambridge University Press.

Sierra, L. (1947) "La ciencia y las creencias de Julian Huxley, director general de la Unesco". Arbor, 7 (20), pp. 262-270.

Smocovitis, V. B. (2014) "Disciplining and popularizing: Evolution and its publics from the modern synthesis to the present". Studies in History and Philosophy of Biological and Biomedical Sciences, 45, pp. 111-113.

Spann, O. (1933) Filosofía de la sociedad. Madrid: Revista de Occidente.

Teich, M. (1975) "A single path to the double helix?". History of Science, 8, pp. 264-283. doi. https://doi. org/10.1177/007327537501300403

Templado, J. (1960) "Coloquio sobre evolución biológica". Arbor, 45 (170), pp. 99-102.

Uexküll, J. von (1922) Ideas para una concepción biológica del mundo., Madrid: Calpe.

Vázquez Dodero, J. L. (1934) "La mentalidad de nuestro tiempo y los tópicos muertos". Acción Española, 66, p. 547.

Vegas Latapié, E. (1987) "Partidos Políticos Católicos". In: Q. Aldea Vaquero, Marín Martínez, T. and J. Vives, ed., Diccionario de Historia Eclesiástica de España, Madrid: CSIC, pp. 588589.

Weizsäcker, C. F. von (1943) Zum Weltbild der Physik. Leipzig: Hirzel.

Ynfante, J. (1970) La prodigiosa aventura del Opus Dei. París: Ruedo Ibérico.

Zubiri, X. (1974) Naturaleza, Historia, Dios. $6^{\text {th }}$ ed. Madrid: Editora Nacional. 